\title{
PENGARUH PENDIDIKAN DAN PELATIHAN TERHADAP KINERJA PEGAWAI DINAS PENDIDIKAN PEMUDA DAN OLAHRAGA KABUPATEN DOMPU
}

\author{
Abdul Suhud ${ }^{1}$ \\ ${ }^{1}$ Badan Kepegawaian Kabupaten Dompu, suhud.bkd@gmail.com
}

\begin{abstract}
This research is an explanatory research which is empirical investigation, and the investigation did not control the variable directly, because the realization of these variables is basically no manipulation. Subject in this study were official of Departemen Education Youth dan Sports in Dompu Regency is divided into 5 unit with a population of as many as 87 people. Sampling was conducted using proportional random sampling technique, where in each part of the work unit taken some of its members in accordance with the size of the number of official. The number of samples used is 72 people. Data analysis was performed using multiple regression analysis to see the effect of education and training and degree of education on on performance of official.

Based on the results of this study found that education and training and degree of education either partially or simultaneously affect to the performance on Official of Education, Youth and Sport in Dompu Regency so always maintain the performance of officials by providing opportunities for officials to participate in education and training of officials, and always recruit officials based on their degree of education and provide an opportunity to raise the degree of education is shown to have a significant influence on performance of official.
\end{abstract}

Keywords : Education and training, performenace of official

\begin{abstract}
ABSTRAK
Penelitian ini bertujuan untuk menganalisis pengaruh pendidikan, pelatihan terhadap kinerja pegawai. Penelitian ini termasuk penelitian explanatory research yaitu penyelidikan secara empiris, dan peneliti tidak mengendalikan variabel bebas secara langsung, karena perwujudan variabel tersebut pada dasarnya tidak ada manipulasi.Subjek dalam penelitianm ini adalah pegawai di lingkungan Dinas Pendidikan Pemuda dan Olahraga Kabupaten Dompu yang terbagi 5 unit dengan jumlah populasi 87 orang. Pengambilan sampel dilakukan menggunakan teknik proposional random sampling, dimana pada setiap bidang diambil sebagai anggotanya sesuai dengan ukuran jumlah pegawainya. Jumlah sampel yang digunakan yaitu 72 orang. Analisis data dilakukan dengan menggunakan analisis regresi berganda untuk melihat pengaruh Pendidikan dan Pelatihan terhadap Kinerja Pegawai.

Berdasarkan hasil penelitian ini ditemukan bahwa Pendidikan dan Pelatihan baik secara parsial maupun simultan berpengaruh positif terhadap kinerja pegawai Dinas Pendidikan Pemuda dan Olahraga Kabupaten Dompu. Oleh karena itu bagi Dinas Pendidikan Pemuda dan Olahraga Kabupaten Dompu supaya selalu meningkatkan kinerja pegawai dengan memberikan kesempatan kepada pegawai untuk mengikuti pendidikan dan mengadakan pelatihan pegawai sesuai yang terbukti memiliki pengaruh yang signifikan terhadap kinerja pegawai.
\end{abstract}

Kata Kunci : Pendidikan dan Pelatihan, Kinerja Pegawai

\section{PENDAHULUAN}

Pengembangan sumber daya manusia berbasis kompentensi membutuhkan sumber daya manusia (karyawan) yang berkualitas. Keberadaan karyawan dalam organisasi memiliki posisi yang sangat vital. Keberhasilan organisasi sangat ditentukan oleh kualitas orang-orang yang bekerja di dalamnya. Perubahan lingkungan yang begitu cepat menuntut kemampuan mereka dalam menangkap fenomena perubahan tersebut, 
pengembangan sumber daya manusia tidak hanya perbaikan atau penataan tata kelola administrative tetapi juga mengarah pada kemampuan mengembangkan potensi sumber daya manusia agar menjadi kreatif da inovatif

Berbagai upaya yang dilakukan pemerintah dalam proses pengembangan sumber daya manusia, memberikan ruang bagi karyawan atau pegawai untuk mengikuti berbagai program pendidikan dan pelatihan seperti pendidikan dan pelatihan struktural, pendidikan dan pelatihan fungsional maupun pendidikan dan pelatihan teknis yang diselenggarakan oleh lembaga swasta maupun diselenggarakan oleh lembaga pemerintah seperti Lembaga Adminsitrasi Negara (LAN), Kemendagri atau instansiinstansi pemerintah lainnya.

Pendidikan dengan berbagai programnya mempunyai peranan penting dalam proses memperoleh dan meningkatkan kualitas kemampuan professional individu. Melalui pendidikan seseorang dipersiapkan untuk memiliki bekal agar siap tahu, mengenal dan mengembangkan metode berfikir secara sistematis agar dapat memecahkan masalah yang akan dihadapi dalam kehidupan dikemudian hari. Pendidikan dan pelatihan mempunyai fungsi sebagai penggerak sekaligus pemacu terhadap potensi kemampuan sumber daya manusia dalam meningkatkan prestasi kerjanya, kompetensi seseorang pekerja dapat dipupuk melalui program pendidikan, pengembangan dan pelatihan

Pegawai Aparatur Sipil Negara sebagai unsur utama sumber daya aparatur negara mempunyai peranan yang menentukan keberhasilan penyelenggaraan pemerintahan dan pembangunan diharapkan memiliki kompetensi yang diindikasikan dari sikap dan perilaku yang penuh dengan kesetiaan dan ketaatan kepada negara, bermoral dan bermental baik, professional, sadar akan tanggung jawabnya sebagai pelayan publik. Dalam konteks manajemen kepegawaian, pendidikan dan pelatihan jabatan Pegawai Aparatur Sipil Negara adalah proses penyelenggaraan belajar mengajar dalam rangka meningkatkan kemampuan Pegawai Apratur Sipil Negara (Pasal 1, Peraturan Pemerintah Nomor 101 Tahun 2000). Dalam Pasal 2 Peraturan Pemerintah tersebut disebutkan bahwa diklat bertujuan untuk :

1. Meningkatkan pengetahuan, keahlian, keterampilan dan sikap untuk dapat melaksanakan tugas jabatan secara professional dengan dilandasi kepribadian dan etika PNS sesuai dengan kebutuhan instansi;

2. Menciptakan aparatur yang mampu berperan sebagai pembaharu dan perekat persatuan dan kesatuan bangsa

3. Memantapkan sikap dan semangat pengabdian yang berorientasi pada pelayanan, pengayoman dan pemberdayaan masyarakat;

4. Menciptakan kesamaan visi dan dinamika pola pikir dalam melaksanakan tugas pemerintahan umum dan pembangunan demi terwujudnya pemerintahan yang baik.

Untuk menambah nilai guna Pegawai ASN, pihak Dinas Dikpora memberikan kesempatan kepada pegawai untuk mengikuti pendidikan dan pelatihan setiap tahunnya, antara lain dengan memberikan kesempatan untuk tugas belajar/ijin belajar pada Strata 1, Strata 2 maupun Strata 3. Disamping pendidikan, diberikan pula kesempatan untuk mengikuti pelatihan manajemen kepegawaian yang diselenggarakan pada tingkat Kabupaten, Provinsi dan Nasional sebagaimana dalam tabel dibawah ini. 
Tabel 1. Data Pegawai ASN Dinas Dikpora yang mengikuti pendidikan tugas belajar/ijin belajar

\begin{tabular}{|c|c|c|c|c|c|}
\hline \multirow{2}{*}{ JENJANG } & \multicolumn{4}{|c|}{ TAHUN } & \multirow{2}{*}{ JUMLAH } \\
\hline & 2012 & 2013 & 2014 & 2015 & \\
\hline SMP & & & & & 0 \\
\hline SMA & & & & & 0 \\
\hline D. 2 & 1 & & & & 1 \\
\hline D. 3 & & & & & 3 \\
\hline S.1/D.IV & 1 & 2 & 2 & & 5 \\
\hline S.2 & 1 & & & & 1 \\
\hline S.3 & 1 & & & & 1 \\
\hline \multicolumn{5}{|c|}{ JUMLAH } & 11 \\
\hline
\end{tabular}

Sumber : BKD Dompu

Terlihat bahwa ASN pada Dinas Dikpora yang mengikuti kegiatan pendidikan (tugas belajar) yaitu Diploma Dua (D.2) 1 Orang dan S1 dan setara sebanyak 5 Orang, bahkan ada dua orang yang masing-masing yang telah melanjutkan studi ke jenjang S2 satu orang dan S3 satu orang. Selanjutnya pada Tabel 2, menggambarkan ASN yang mengikuti pelatihan

Tabel 1, Data Pegawai ASN Dinas Dikpora yang mengikuti Pelatihan

\begin{tabular}{|c|c|c|c|c|c|}
\hline \multirow{2}{*}{ JENIS DIKLAT } & \multicolumn{4}{|c|}{ TAHUN } & \multirow{2}{*}{ JUMLAH } \\
\hline & 2012 & 2013 & 2014 & 2015 & \\
\hline Kepemimpinan & 5 & 4 & 5 & 5 & 19 \\
\hline Teknis & 6 & 6 & 7 & 7 & 26 \\
\hline Fungsional & 10 & 9 & 8 & 8 & 35 \\
\hline \multicolumn{5}{|c|}{ JUMLAH } & 80 \\
\hline
\end{tabular}

Sumber : Dikpora Dompu

Dinas Pendidikan Pemuda dan Olahraga merupakan unsur pelaksana Pemerintah Daerah dipimpin oleh Kepala Dinas yang berada dibawah dan bertanggung jawab kepada Bupati melalui Sekda. Dinas Pendidikan Pemuda dan olahraga mempunyai tugas membantu Bupati dalam melaksanakan urusan pemerintahan daerah bidang pendidikan dan dan bidang pemuda dan olahraga berdasarkan asas otonomi dan tugas perbantuan.

Pengembangan pegawai yang dilakukan oleh Dinas Dikpora bertujuan untuk memaksimalkan kinerja masing-masing pegawai dengan harapan dapat memberikan pelayanan yang maksimal terhadap 2.784 pegawai dari 6.042 pegawai ASN Lingkup Pemerintah Kabupaten Dompu. Dinas Dikpora memiliki tugas untuk menangangi administrasi kepegawaian bagi pejabat struktural, pejabat fungsional dan tenaga administrasi yang tersebar pada Dinas Dikpora itu sendiri, dan lembaga pendidikan tingkat SDN, SMP dan SMA pada tiap-tiap kecamatan se-kabupaten Dompu.

Berdasarkan hasil observasi yang dilakukan oleh peneliti pada saat melakukan survei awal di lingkungan Dinas Pendidikan Pemuda dan Olahraga Kabupaten Dompu, untuk meningkatkan kinerja para pegawai di Lingkungan Dinas Dikpora Kabupaten Dompu, pimpinan membuat kebijakan untuk mengukur tingkat kepatuhan terhadap jam kerja dan kehadiran pegawai dengan melakukan rekapitulasi daftar hadir setiap 2 (dua) bulan sekali. Disamping melakukan rekapitulasi daftar hadir secara berkala juga 
dilakukan pembuatan agenda kerja atau laporan kerja harian sesuai dengan tugas masing-masing per tiga jam untuk mengetahui pekerjaan dan hasil yang dicapai.

Untuk memastikan kualitas pelayanan dan mengikuti tuntutan kebutuhan, Dinas Dikpora memberikan kesempatan kepada kurang lebih 4 sampai 5 orang per tahun untuk mengikuti berbagai jenis pendidikan dan pelatihan, namun sampai saat ini belum ada evaluasi tentang hasil dan manfaat bagi PNS yang mendapatkan kesempatan mengikuti pendidikan dan pelatihan. Hal ini terlihat masih adanya kesalahan-kesalahan yang dilakukan menyelesaikan berkas kepegawaian seperti berkas usulan kenaikan pangkat dan usulan pengangkatan dalam jabatan fungsional, kesalahan-kesalahan tersebut dilakukan secara berulang-ulang. Oleh karena itulah peneliti tertarik untuk mengadakan penelitian berkenaan dengan pengaruh Pelaksanaan Pendidikan dan Pelatihan terhadap Kinerja Pegawai Dinas Pendidikan Pemuda dan Olahraga Kabupaten Dompu.

\section{PERUMUSAN MASALAH}

Dalam penelitian ini penulis mencoba merumuskan permasalahan sebagai berikut.

1. Apakah pendidikan memiliki pengaruh terhadap kinerja pegawai di Lingkungan Dinas Pendidikan Pemuda dan Olahraga Kabupaten Dompu?

2. Apakah pelatihan memiliki pengaruh terhadap kinerja pegawai dilingkungan Dinas Pendidikan Pemuda dan Olahraga Kabupaten Dompu?

3. Apakah pendidikan dan pelatihan secara bersama-sama memiliki pengaruh terhadap kinerja pegawai dilingkungan Dinas Pendidikan Pemuda dan Olahraga Kabupaten Dompu?

\section{KERANGKA TEORITIS}

Penelitian yang dilakukan oleh Farida (2010) dengan judul Pengaruh Pendidikan Formal, Pelatihan, Dan Pengembangan Karier Terhadap Kinerja Pegawai Perempuan (Studi di Kota Bandar Lampung). Hasil penelitian memperlihatkan bahwa terdapat pcngaruh signifikan antara pendidikan formal, pelatihan,dan pengembangan karier pegawai terhadap kinerja pegawai perempuan.

Penelitian yang dilakukan oleh Supangat (2010) dengan judul Pengaruh Pendidikan Dan Pelatihan Serta Lingkungan Kerja Terhadap Kinerja Pegawai Pembimbing Kemasyarakatan Balai Pemasyarakatan Klas I Medan. Hasil penelitian dari hipotesis pertama memperlihatkan bahwa pendidikan dan pelatihan serta lingkungan kerja mempunyai pengaruh signifikan terhadap kinerja pegawai Pembimbing Kemasyarakatan (PK) di Kantor Balai Pemasyarkatan Klas I Medan. Sedangkan hasil penelitian pada hipotesis kedua menggambarkan bahwa terdapat perbedaan kinerja Pembimbing Kemasyarakatan (PK) sebelum dan sesudah dilaksanakannya pendidikan dan pelatihan, sehingga mempunyai perbedaan yang positif dan signifikan terhadap kinerja pegawai Pembimbing Kemasyarakatan (PK) di Kantor Balai Pemasyarkatan Klas I Medan.

Penelitian yang dilakukan oleh Dhafi (2011) dengan judul Analisis Pengaruh Pendidikan Dan Pelatihan Serta Pengembangan Karir Terhadap Kinerja Personil Satlantas Pada Unit Penegakan Hukum Dan Penyidikan Kecelakaan Kepolisian Resort Di Deli Serdang. Hasil penelitian dari hipotesis pertama memperlihatkan bahwa

4 | Pengaruh Pendidikan Dan Pelatihan Terhadap Kinerja Pegawai... 
pendidikan dan pelatihan serta pengembangan karir berpengaruh signifikan terhadap kinerja personel Satlantas Polres Deli Serdang secara simultan maupun parsial. Sedangkan hasil penelitian pada hipotesis kedua memperlihatkan bahwa terdapat perbedaaan kinerja personil pada unit penegakan hukum dan penyidikan kecelakaan Polres Deli Serdangsebelum dan sesudah pelaksanaan pendidikan dan pelatihan, dan hipotesis ketiga menunjukkan adanya perbedaaan kinerja personil pada unit penegakan hukum dan penyidikan kecelakaan Polres Deli Serdang sebelum dan sesudah pelaksanaan pengembangan karir.

Penelitian yang dilakukan oleh Harianto (2007) dengan judul Pengaruh Pendidikan Dan Pelatihan Terhadap Kinerja Karyawan Pada Kantor Pelayanan Bea dan Cukai Palembang. Hasil penelitian memperlihatkan pendidikan dan pelatihan berpengaruh signifikan terhadap kinerja karyawan padakantor pelayanan bea dan cukai Palembang baik secara parsial maupunsimultan. Penelitian dilakukan oleh Sulistyaningsih (2008) yang melakukan penelitian tentang Pengaruh Pendidikan dan Pelatihan (Diklat), Lingkungan Kerja, Tingkat Pendidikan Dan Kepemimpinan Terhadap Kinerja Pegawai Negeri Sipil Pada Dinas Pendidikan Dan Kebudayaan Kabupaten Karanganyar. Hasil penelitian menunjukkan bahwa pendidikan dan pelatihan serta tingkat pendidikan berpengaruh terhadap kinerja pegawai.

Penelitian dilakukan oleh Haryanti dan Susialisasi (2008) tentang Pengaruh Tingkat Pendidikan, Lingkungan Kerja Dan Masa Kerja Terhadap Kinerja Kepala Sekolah SMP Negeri Se-Kabupaten Karanganyar Dengan Gender Sebagai Variabel Moderator. Hasil penelitian menunjukkan bahwa tingkat pendidikan berpengaruh terhadap kinerja pegawai.

Penelitian yang dilakukan oleh Supriadi (2013) tentang Pengaruh Pendidikan dan Pelatihan terhadap Kinerja Pegawai di Lingkungan Unit Pelaksana Teknis Dinas Pendidikan, Pemuda dan Olahraga Kecamatan VII Koto Ilir Kabupaten Tebo. Hasil penelitian menunjukkan bahwa pendidikan dan pelatihan secara simultan berpengaruh positif dan signifikan terhadap kinerja pegawai.

Penelitian yang dilakukan oleh Arifuddin (2013) tentang Pengaruh Pendidikan dan Pelatihan dan Motivasi Kerja terhadap Kinerja Pegawai pada Badan Kepegawaian Daerah Kabupaten Dompu. Penelitian yang dilakukan oleh Andersen (2013) tentang Pengaruh Pendidikan Pelatihan dan Lingkungan Kerja terhadap Kinerja Kepala Desa di Kabupaten Indragiri Hilir. Hasil Penelitian menunjukkan bahwa variabel diklat secara simultan mempunyai pengaruh signifikan terhadap kinerja kepala desa. Penelitian yang dilakukan oleh Falery (2013) tentang Pengaruh Pendidikan dan Pelatihan, Lingkungan Kerja dan Gaya Kepemimpinan terhadap Kinerja Anggota Satuan Polisi Pamong Praja Provinsi Kalimantan Tengah. Hasil penelitian menunjukkan bahwa pendidikan dan pelatihan berpengaruh positif dan signifikan terhadap kinerja Satuan Polisi Pamong Praja.

Perbedaan penelitian ini dengan penelitian sebelumnya yaitu variabel yang digunakan, dimana dimaksud dengan pendidikan dan pelatihan adalah dua variabel yang berbeda. Pendidikan menunjukkan kepada tingkat pendidikan pegawai, dan pelatihan menunjukkan kepada tingkatan pelatihan yang diikuti oleh pegawai. Pada penelitian terdahulu, variabel pendidikan dan variabel pelatihan yang dimaksud adalah diklat yang diikuti oleh pegawai, sedangkan faktor pendidikan disebutkan sebagai tingkat pendidikan formal. Perbedaan lain dengan penelitian terdahulu yaitu pemilihan subjek penelitian yang berbeda yang tentunya memiliki karakteristik yang berbeda pula. 


\section{HIPOTESIS}

Melalui pendidikan dan pelatihan akan memungkinkan melahirkan para pegawai yang memiliki kinerja yang baik pula. Hal ini dapat dilihat pada bagan berikut ini :

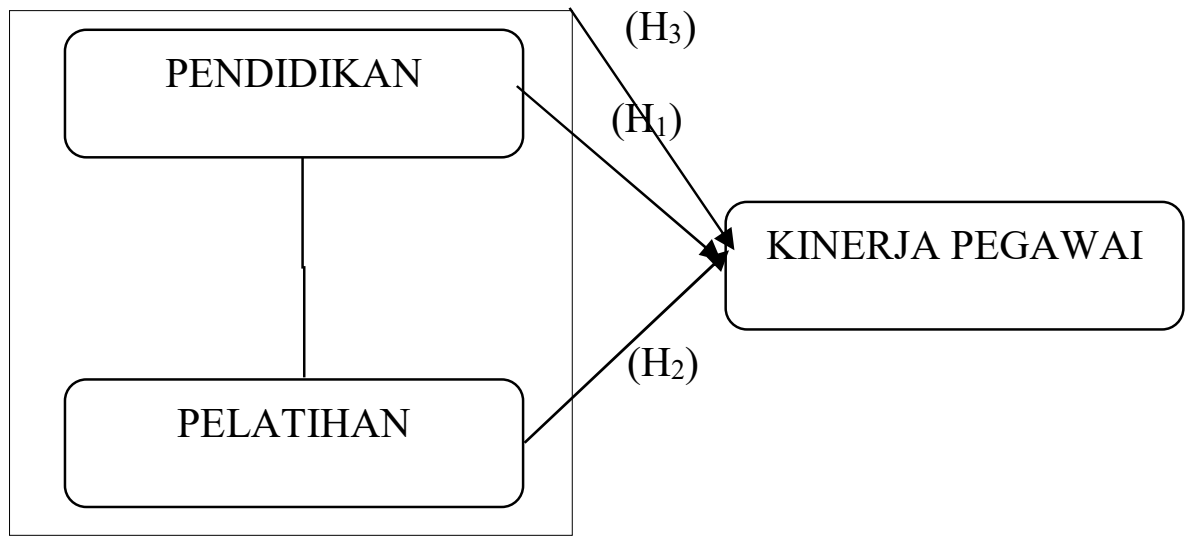

Gambar 1 Desain Penelitian

Berdasarkan Gambar 1 tersebut, dapat dikemukakan hipotesis sebagai berikut:

1. $\mathrm{H}_{1}$ : Pendidikan perpengaruh positif terhadap kinerja pegawai pada Dinas Pendidikan Pemuda dan Olahraga Kabupaten Dompu.

2. $\mathrm{H}_{2}$ : Pelatihan berpengaruh positif terhadap kinerjapegawai Dinas Pendidikan Pemuda dan Olahraga Kabupaten Dompu.

3. $\mathrm{H}_{3}$ : Pendidikan dan pelatihan secara bersama-sama (simultan) berpengaruh positif terhadap kinerja pegawai pada Dinas Pendidikan Pemuda dan Olahraga Kabupaten Dompu.

\section{METODE PENELITIAN}

\section{Desain Penelitian}

Penelitian ini termasuk penelitian Asosiatif. Menurut Siregar (2014:14) yaitu suatu penelitian yang bertujuan untuk mengetahui hubungan antara dua variabel atau lebih. Dengan penelitian ini, maka akan dapat dibangun suatu teori yang dapat berfungsi untuk menjelaskan, meramalkan, dan mengontrol suatu gejala dalam penelitian.

\section{Populasi dan Sampel}

Populasi

Populasi untuk penelitian ini adalah Pegawai Aparatur Sipil Negara pada Dinas Pendidikan Pemuda dan Olahraga Kabupaten Dompu yang berjumlah 87 orang.

Sampel

Penentuan Jumlah Sampel

Penentuan jumlah sampel menggunakan teknik Solvin sebagai berikut :

$$
n=\frac{N}{1+N e^{2}}
$$

Keterangan : $\mathrm{n}=$ sampel, $\mathrm{N}=$ populasi, $e=$ perkiraan tingkat kesalahan

6 | Pengaruh Pendidikan Dan Pelatihan Terhadap Kinerja Pegawai... 


$$
\begin{aligned}
& n=\frac{87}{1+87(0,05)^{2}}=71.46 \\
& \text { sampel minimal yang bisa digunakan sebagai responden penelitian } \\
& \text { yaitu sebanyak } 72 \text { orang. }
\end{aligned}
$$

Teknik Pengambilan Sampel

Pengambilan sampel dilakukandenganteknik simple random sampling, merupakan teknik pengambilan sampel yang memberikan kesempatan yang sama kepada setiap anggota yang ada dalam suatu populasi untuk dijadikan sampel.

\section{Instrumen Penelitian}

Alat pengumpul data pada penelitian ini berupa angket/kuesioner. Angket/kuesioner yang digunakanadalah angket tertutup, karena responden tinggal memilih jawaban yangdisediakan.Pengumpulan datadiperlakukandengan menggunakan angket yang disebarkan terhadap responden penelitian.

Angket/kuesioner digunakan untuk menemukan data empiris dengan menggunakanangket/kuesioner dengan Skala Likert.Penggunaan kuesioner dimaksudkan untuk mengumpulkan data variabel penelitian yaitu kinerja pegawai.Responden diminta mengisi pernyataan dalam skala ordinal (Umar, 2008: 7071). Skala pengukuran adalah Skala Likert yang dibagi kedalam lima pengukuran yaitu:

$\begin{array}{lll}\text { STS } & = & \text { Sangat Tidak Setuju, diberi bobot } 1 \\ \text { TS } & = & \text { Tidak Setuju Setuju, diberi bobot } 2 \\ \text { Rg } & = & \text { Netral, diberi bobot } 3 \\ \text { S } & = & \text { Setuju, diberi bobot } 4 \\ \text { SS } & = & \text { Sangat Setuju, diberi bobot } 5\end{array}$

Uji Validitas

Menurut Priyatno (2008:16), Uji validitas adalah ketepatan atau kecermatan suatu instrumen dalam mengukur apayang ingin diukur. Dalam penelitian ini uji validitas mengukur sejauh mana kuesioner mampu mengukur hubungan pendidikan dan pelatihan dengan kinerja pegawai.

Uji Reabilitas

Uji reliabilitas dimaksudkan untuk mengetahui apakah jawaban yang diberikan responden dapat dipercaya atau dapat diandalkan, apabila dilakukan dua kali pengukuran atau lebih terhadap objek dengan alat ukur yang sama. Prosedur Pengumpulan Data

\section{JENIS DAN SUMBER DATA}

\section{Data Primer}

Adalah data yang langsung diperoleh dari sumber data pertama di lokasi penelitian atau obyek penelitian (Bungin, 2005:12). Dalam hal ini dataprimeryang digunakan dalam penelitian ini adalah data jawabanresponden yang diambil melalui isian kuesioner

Data Sekunder

Adalah data yang diperoleh secara tidak langsung, yaitu melalui buku-buku dan dokumen-dokumen (Bungin, 2005:12). Dalam hal ini datasekunder yang digunakan 
dalam penelitian ini adalah literatur atau buku-buku perpustakaan, dan dokumen penunjang yang dimiliki Dinas Pendidikan Pemuda dan Olahraga Kabupaten Dompu.

Teknik pengumpulan data dalam penelitian ini dilakukan denganmenggunakan kuesioner.Angket/kuesioner yang digunakan adalah angkettertutup, karena respondentinggal memilihjawaban yang disediakan. Pengumpulan data diperlakukan dengan menggunakan angket yang disebarkan kepada responden penelitian.

\section{METODE ANALISIS DATA}

\section{Statistik Deskriptif}

Statistik deskriptif memberikan gambaran atau deskripsisuatu data dengan menggunakan teknik persentase. Rumus persentase yang digunakan menurut Arikunto(2006) sebagai berikut:

$\mathrm{P}=\frac{f}{n} \times 100 \%$

Dimana

$\begin{array}{lll}\mathrm{P} & = & \text { Persentase } \\ \mathrm{f} & = & \text { Skor item yang dihitung } \\ \mathrm{n} & = & \text { Skor yang diharapkan }\end{array}$

Hasil jawaban angket disusun berdasarkan kriteria penilaian jawaban angket yang disusun dalam tabel distribusi frekuensi sebagai berikut :

Tabel 3. Kriteria Penilaian Hasil Jawaban Kuisioner

\begin{tabular}{|c|c|}
\hline Interval Prosentase (\%) & Kriteria \\
\hline $81-100$ & Sangat tinggi/Baik Sekali \\
\hline $61-80$ & Tinggi/Baik \\
\hline $41-60$ & Cukup \\
\hline $21-40$ & Rendah/kurang baik \\
\hline $0-20$ & Sangat Rendah/Buruk \\
\hline
\end{tabular}

Sumber: (Riduan, 2008: 15)

\section{Uji Asumsi Klasik}

Pengujian asumsi klasik yang digunakan dalam penelitian ini adalah uji multikolinearitas, uji heteroskedastisitas, Uji Normalitas

\section{Analisis Regresi Berganda}

Secara umum formulasi dari regresi sederhana dapat ditulis sebagai berikut:

$\mathrm{Y}=\mathrm{a}+\mathrm{b}_{1} \mathrm{X}_{1}+\mathrm{b}_{2} \mathrm{X}_{2}$

Keterangan

$\begin{array}{ll}\mathrm{Y} & =\text { Kinerja pegawai } \\ \mathrm{a} & =\text { Nilai intercept/constant } \\ \mathrm{b} & =\text { Koefisien regresi variabel independen } \\ \mathrm{X}_{1} & =\text { Pendidikan } \\ \mathrm{X}_{2} & =\text { Pelatihan }\end{array}$

\section{Pengujian Hipotesis}

Uji t (Uji Parsial)

Pengujian ini bertujuan untuk menjawab rumusan masalah yang pertama dan kedua yaitu mengetahui adanya pengaruh dan masing-masing variabel bebas secara

8 | Pengaruh Pendidikan Dan Pelatihan Terhadap Kinerja Pegawai... 
parsial terhadap variable terikatnya. Apabila tingkatsignifikansiyang diperoleh $t_{\text {hitung }} \geq$ $t_{\text {tabel }}$ pada taraf signifiansi $\alpha=0,05$, makaH $_{0}$ dapat ditolak atau dengan $\alpha=0,05$ variabel independen tersebut berpengaruh secara statistis terhadap variabel dependennya.

\section{Uji F (Uji Simultan)}

Uji ini dilakukan untuk menjawab rumusan masalah yang ketiga yaitu mengetahui ada tidaknya pengaruh yang signifikan atas semua variabel independen (pendidikandan pelatihan) terhadap terhadap variabel dependen (kinerja pegawai) secara keseluruhan. Uji-Fdilakukan dengan caramembandingkan $\mathrm{F}_{\text {value }}\left(\mathrm{F}_{\text {hitung }}\right)$ yang diperoleh dari hasil regresi dengan $\mathrm{F}$-significant $\left(\mathrm{F}_{\text {tabel }}\right)$ yang ditetapkan.

Jika $\mathrm{F}_{\text {hitung }} \geq \mathrm{F}_{\text {tabel }}$ pada taraf signifikansi $(\alpha=0.05)$ maka hipotesis diterima, artinya variabel independen tidak berpengaruh terhadap variable dependen.

Jika $\mathrm{F}_{\text {hitung }}<\mathrm{F}_{\text {tabel }}$ pada taraf signifikansi $(\alpha=0.05)$ maka hipotesis ditolak, artinya variabel independen berpengaruh terhadap variabel dependen.

Koefisien Determinasi

Nilai R-squared $\left(\mathrm{R}^{2}\right)$ statistik mengukur tingkat keberhasilan model regresi yang kita gunakan dalam memprediksi nilai variahel terikat. Atau dengan kata lain $\mathrm{R}^{2}$ menunjukkan berapa persen variabel bebas yang digunakan dapat menjelaskan variabel terikatnya. Hal ini berarti seberapa besar pengaruh variabel bebas (pendidikan dan pelatihan) terhadap variahel terikatnya (kinerja pegawai). $\mathrm{R}^{2}$ merupakan fraksi dan variasi yang mampu dijelaskan oleh model.Nilai $\mathrm{R}^{2}$ terletak antara nol hingga satu, Semakin mendekati satu maka model dapat kita katakan semakin baik.

\section{ANALISIS DATA}

\section{Uji Validitas}

Uji Validitas adalah ketepatan atau kecermatan suatu instrument dalam mengukur apa yang ingin diukur (Priyatno, 2008:16). Dalam penelitian ini uji validitas mengukur sejauh mana kuisioner mampu mengukur hubungan pendidikan dan pelatihan dengan kinerja pegawai. Untuk menentukan tingkat validitas, peneliti menggunakan bantuan program Statistical Product and Srevice Solution (SPSS) Versi 17.00. Hasil korelasi dibandingkan dengan angka kritis tabel korelasi untuk degree or freedom $(\mathrm{df})=$ $\mathrm{n}-2$, dalam hal ini $\mathrm{n}$ adalah jumlah sampel. Dasar pengambilan keputusan diambil, jika nilai hasil uji validitas lebih besar dari nilai angka kritis tabel korelasi, maka item pertanyaan tersebut dikatakan valid. dibawah ini :

Hasil uji validitas instrumen kuisioner kinerja pegawai dapat dilihat pada tabel

Tabel 4. Hasil Uji Validitas Kuisioner Kinerja Pegawai

\begin{tabular}{|c|c|c|c|}
\hline No Item & $\mathbf{r}_{\text {itung }}$ & $\mathbf{r}_{\text {tabel }}$ & Validitas \\
\hline 1 & 0,616 & 0,235 & Valid \\
\hline 2 & 0,607 & 0,235 & Valid \\
\hline 3 & 0,613 & 0,235 & Valid \\
\hline 4 & 0,638 & 0,235 & Valid \\
\hline 5 & 0,641 & 0,235 & Valid \\
\hline 6 & 0,699 & 0,235 & Valid \\
\hline 7 & 0,720 & 0,235 & Valid \\
\hline 8 & 0,753 & 0,235 & Valid \\
\hline 9 & 0,569 & 0,235 & Valid \\
\hline 10 & 0,608 & 0,235 & Valid \\
\hline
\end{tabular}




\begin{tabular}{|c|c|c|c|}
\hline No Item & ritung $_{\text {itabel }}$ & Validitas \\
\hline 11 & 0,704 & 0,235 & Valid \\
\hline 12 & 0,760 & 0,235 & Valid \\
\hline 13 & 0,677 & 0,235 & Valid \\
\hline 14 & 0,643 & 0,235 & Valid \\
\hline 15 & 0,616 & 0,235 & Valid \\
\hline 16 & 0,661 & 0,235 & Valid \\
\hline 17 & 0,559 & 0,235 & Valid \\
\hline
\end{tabular}

Sumber : Data Primer diolah

Berdasarkan hasil uji validitas, setiap item pertanyaan yang valid mempunyai korelasi yang tinggi dengan jumlah total skor seluruh item pertanyaan, dimana nilai $\mathrm{r}_{\text {hitung }}>\mathrm{r}_{\text {tabel }}$ dengan $\alpha=0,05$ dan $\mathrm{N}=72$ yaitu 0,235 . Dari hari hasil uji validitas ditemukan bahwa 17 item pertanyaan dinyatakan valid dan bisa digunakan sebagai alat pengumpulan data kinerja pegawai.

\section{Uji Reliabilitas}

Uji reliabilitas digunakan untuk mengetahui konsistensi alat ukur, apakah alat ukur yang digunakan dapat dihandalkan dan tetap konsisten jika pengukuran tersebut diulang (Priyatno, 2008:25). Dalam penelitian ini menggunakan metode Alpha (Cronbach's) karena metode Alpha sangat cocok digunakan pada skor berbentuk skala. Nilai koefisien alpha dibandingkan dengan angka kritis tabel korelasi pada taraf signifikansi $\alpha=0,05$. Jika nilai hasil uji reliabilitas lebih besar dari angka kritis tabel korelasi, maka instrumen yang digunakan tersebut dikatakan reliabel (Arikunto, 2006:177).

Berdasarkan hasil uji reliabilitas, diperoleh harga koefisein alpha variabel kinerja pegawai sebesar 0,900 , lebih besar dari $\mathrm{r}$ dalam tabel $\mathrm{r}$ produk momen dengan $\alpha$ $=0,05$ dab $\mathrm{n}=72$ yaitu 0,235 . Hal ini berarti bahwa instrumen kuisioner dinyatakan reliabel sehingga dapat digunakan sebagai alat ukur yang baik untuk memperoleh data variabel kinerja pegawai

\section{Uji Multikolineritas}

Uji multikolineritas untuk mengetahui apakah pada model regresi ditemukan adanya korelasi antar variabel independen. Prasyarat yang harus terpenuhi dalam model regresi adalah tidak adanya multiklonearitas. Metode pengujiannya dengan melihat nilai inflation factor (VIF) pada model regresi.

Menurut Santoso (2001) dikutip dari Priyatno (2008:39) dan Putra (2007) pada umumnya jika VIF lebih besar dari 5, maka variabel tersebut mempunyai persoalan multikolinearitas dengan variabel bebasnya. Hasil uji multikolinearitas dapat dilihat pada tabel berikut ini :

Tabel 5. Hasil Uji Multikolinearitas

\begin{tabular}{|l|l|r|r|}
\hline \multicolumn{2}{|c|}{ Model } & \multicolumn{2}{c|}{ Collinearity Statistics } \\
\cline { 3 - 4 } \multicolumn{2}{|c|}{1} & Tolerance & \multicolumn{1}{c|}{ VIF } \\
\hline \multirow{3}{*}{} & Constant) & & \\
\cline { 2 - 4 } & Pendidikan & .652 & 1.534 \\
\cline { 2 - 4 } & Pelatihan & .652 & 1.534 \\
\hline
\end{tabular}

a. Dependent Variable: Kinerja

10 | Pengaruh Pendidikan Dan Pelatihan Terhadap Kinerja Pegawai... 
Berdasarkan tabel 4.6 maka dapat diketahui bahwa antara variabel-variabel independen tidak terdapat gangguan multikolinearitas, ini ditunjukkan dengan nilai tolerance yang masing-masing semua variabel independen berkisar pada angka lebih besar dari 0,1 , sedangkan nilai VIF untuk variabel pendidikan dan variabel pelatihan sebesar 1,534 lebih kecil dari 10. Hal ini memperlihatkan bahwa tidak terdapat multikolinearitas pada variabel pendidikan dan pelatihan.

\section{Uji Heteroskedastisitas}

Uji heteroskedastisitas dilakukan untuk mengetahui apakah dalam sebuah model regresi terjadi ketidaksamaan varians dari residual suatu pengamatan ke pengamatan lain. Dalam penelitian ini dilakukan uji heteroskedastisitas dengan cara melihat pola grafis regresi (Priyatno, 2008:41). Hasil uji heteroskedastisitas dapat dilihat pada gambar berikut :

Scatterplot

\section{Dependent Variable: Kinerja}

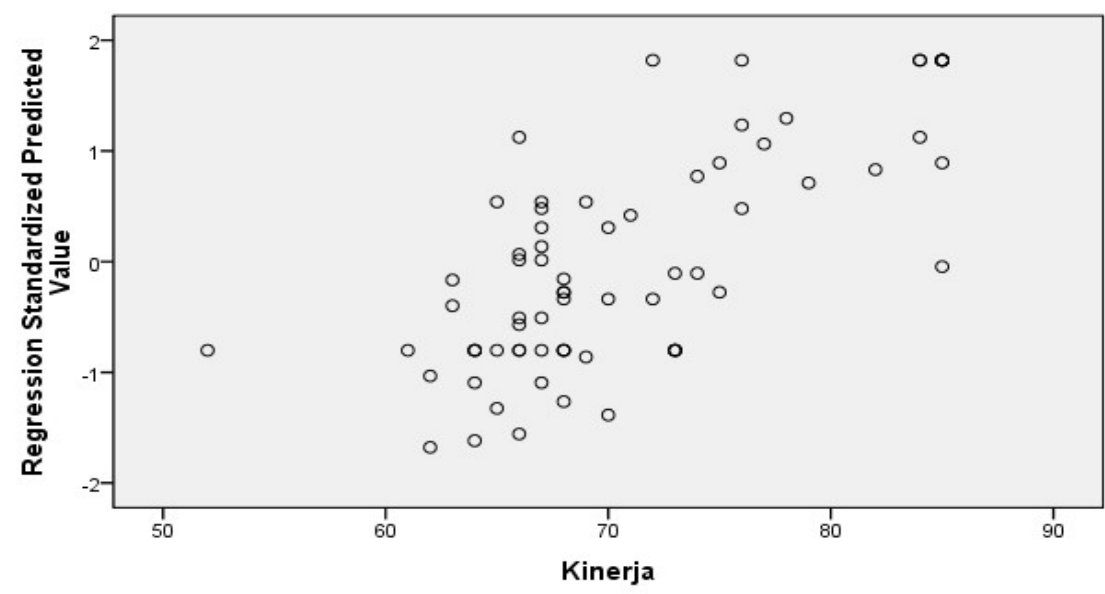

Gambar 2, Grafik Scatterplot Hasil Uji Heterokedastisitas

Pada grafis diatas dapat dilihat bahwa titik-titik pada grafik tersebut menyebar di atas dan di bawah angka nol dan tidak memperlihatkan pola tertentu.Berdasarkan hasil pengujian heteroskedastisitas dengan menggunkan grafik Scatterplot dapat disimpulkan bahwa data tidak mempunyai kecenderungan heteroskedastisitas.

a. Uji Normalitas

Uji normalitas bertujuan untuk menguji variabel independen mempunyai distribusi data normal atau tidak dengan menggunakan Kolmogorov-smirnov atau Normal P-P Plot (Putra, 2006). Model regresi yang baik adalah mempunyai distribusi normal atau mendekati normal pada nilai residual hasil regresi (Ghozali, 2005)

Dari hasil SPSS dapat dilihat distribusi dari model regresi tersebut normal atau tidak dengan cara :

1) Jika data menyebar di sekitar garis diagonal dan mengikuti arah garis diagonal, maka model regresi memenuhi asumsi normalitas.

2) Jika data menyebar jauh dari garis diagonal dan tidak mengikuti arah garis diagonal, maka model regresi tidak mememuhi asumsi normalitas

Hasil uji normalitas dengan metode normal P-Plot yaitu sebagai berikut : 


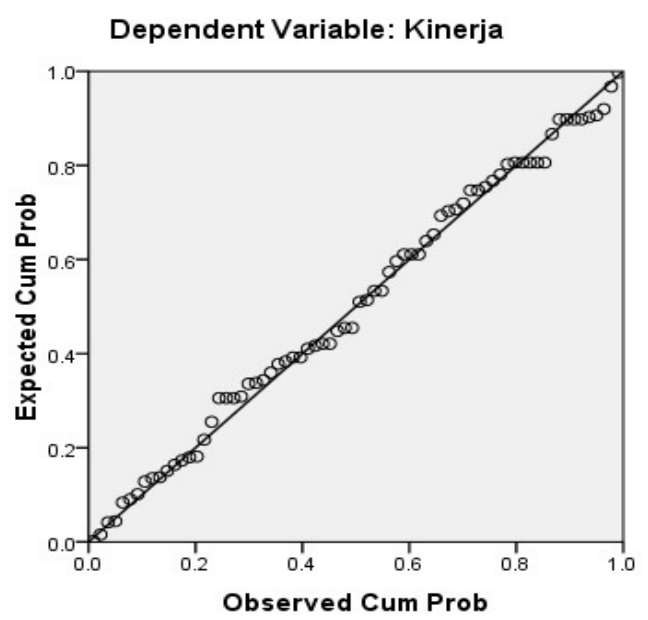

Gambar 3. Uji Normalitas

Berdasarkan grafik diatas dapat dilihat bahwa data menyebar di sekitar garis diagonal dan mengikuti arah garis diagonal.Hal ini bahwa residual hasil regresi memenuhi asumsi normalitas.

\section{b. Koefisien Regresi}

Setelah data ditransformasikan, kemudian dilakukan analisis berganda. Analisis regresi berganda dilakukan dengan menggunakan bantuan program SPSS for Window. Hasil analisis regresi digambarkan dalam tabel sebagai berikut :

Tabel 6.Koefisien Regresi

\begin{tabular}{|c|c|c|c|}
\hline & \multirow{2}{*}{ Model } & \multicolumn{2}{|c|}{ Unstandardized Coefficients } \\
\hline & & $\mathrm{B}$ & Std. Error \\
\hline \multirow[t]{3}{*}{1} & (Constant) & 10.338 & 6.931 \\
\hline & Pendidikan & 1.568 & .333 \\
\hline & Pelatihan & 1.244 & .371 \\
\hline \multicolumn{3}{|c|}{ a. Dependent Variable: Kinerja } & \\
\hline
\end{tabular}

Dari tabel diatas diketahui bahwa nilai konstan yaitu $\alpha=10.338$, sedangkan koefisien variabel pendidikan sebesar 1.568, koefisien variabel pelatihan 1.244. Dari koefisien regresi diatas dibentuk persamaan regresi sebagai berikut :

$. \mathrm{Y}=10.338+1.558 \mathrm{X}_{1}+1.244 \mathrm{X}_{2}$

Koefisien variabel pendidikan $\left(\mathrm{X}_{1}\right)$ sebesar 1,558, hal ini berarti bahwa setiaptingkatan pendidikan akan meningkatkan kinerja pegawai sebesar 1,359\% dengan asumsi variabel yang lain konstan. Sedangkan koefisien variabel pelatihan $\left(\mathrm{X}_{2}\right)$ yaitu sebesar 1,244, hal ini memperlihatkan bahwa setiap satuan pelatihan akanmeningkatkan kinerja pegawai sebesar 1,064\% dengan asumsi variabel yang lain konstan.

Koefisien Determinasi 
Besarnya pengaruh pendidikan dan pelatihan secara bersama-sama terhadap kinerja pegawai dapat dilihat pada nilai koefisien korelasi (R) dan koefisien determinasi $\left(\mathrm{R}^{2}\right)$ dalam tabel berikut ini :

\begin{tabular}{l} 
Tabel 7. Koefisien Regresi \\
\begin{tabular}{|l|r|r|r|r|}
\hline Model & R & R Square & $\begin{array}{c}\text { Adjusted R } \\
\text { Square }\end{array}$ & $\begin{array}{c}\text { Std. Error of } \\
\text { the Estimate }\end{array}$ \\
\hline 1 & $.732^{\mathrm{a}}$ & .536 & .523 & 5.059 \\
\hline a. Predictors: (Constant), Pelatihan, Pendidikan \\
\hline
\end{tabular} \\
b. Dependent Variable: Kinerja \\
\hline
\end{tabular}

Terlihat bahwa besarnya koefisien determinasi $\left(\mathrm{R}^{2}\right)$ yaitu sebesar 0.536 . Hal ini berarti bahwa pendidikan dan pelatihan secara bersama-sama memiliki pengaruh sebesar 0.536 $\mathrm{x} 100 \%=53,6 \%$. Sedangkan sisanya sebesar $46,4 \%$ dipengaruhi faktor lain yang tidak termasuk dalam penelitian.

\section{Hasil Pengujian Hipotesis}

Pengujian hipotesis dilakukan untuk melihat signifikansi pengaruh pendidikan dan pelatihan secara parsial dan simultan terhadap kinerja pegawai. Pengujian hipotesis simultan dilakukan untuk melihat pengaruh pendidikan dan pelatihan secara bersamasama terhadap kinerja pegawai. Pengujian hipotesis simultan dengan menggunakan uji F. Sedangkan pengujian hipotesis secara simultan dan seara parsial yaitu sebagai berikut :

Hasil Uji t (Uji Parsial)

Hasil Uji t dapat dilihat pada tabel 4.6, dimana nilai $t_{\text {hitung }}$ merupakan nilai yang didapat dengan membandingkan koefisien regresi tiap variabel dengan standar error dari koefisien regresi tersebut.Kriteris keputusan dilihat nilai thitung dibandingkan dengan $t_{\text {tabel. }}$

Tabel 8. Hasil Uji t

\begin{tabular}{|l|l|r|r|}
\hline \multicolumn{2}{|c|}{ Model } & \multicolumn{1}{c|}{ t } & \multicolumn{1}{c|}{ Sig. } \\
\hline \multirow{3}{*}{1} & (Constant) & 1.492 & .140 \\
\cline { 2 - 4 } & Pendidikan & 4.708 & .000 \\
\cline { 2 - 4 } & Pelatihan & 3.354 & .001 \\
\hline \multicolumn{2}{|l|}{ a. Dependent Variable: Kinerja } \\
\hline
\end{tabular}

a) Pengujian koefisien regresi pendidikan

Pada variabel pendidikan $\left(\mathrm{X}_{1}\right)$ nilai $\mathrm{t}_{\text {hitung }}$ sebesar 4,708 , sedangkan $t_{\text {tabel }}$ sebesar

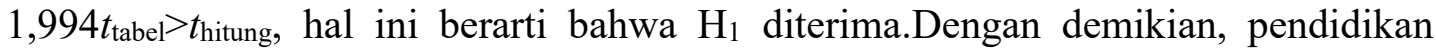
memiliki pengaruh yang seginifikan terhadap kinerja pegawai.

b) Pengujian koefisien regresi pelatihan

Pada variabel pelatihan $\left(\mathrm{X}_{2}\right)$ nilai $\mathrm{t}_{\text {hitung }}$ sebesar 3,354 , sedangkan $t_{\text {tabel }}$ sebesar $1,994 t_{\text {tabel }}<t_{\text {hitung, }}$, hal ini berarti bahwa $\mathrm{H}_{2}$ diterima.Dengan demikian, pelatihan memiliki pengaruh yang seginifikan terhadap kinerja pegawai.

1) Hasil Uji F (Uji Simultan)

Hasil uji $\mathrm{F}$ yang dilakukan untuk melihat pengaruh pendidikan dan pelatihan secara bersama-sama terhadap kinerja pegawai digambarkan dalam tabel berikut ini : 
Tabel 9. Hasil Uji F

\begin{tabular}{|c|c|c|c|c|c|c|}
\hline \multicolumn{2}{|r|}{ Model } & $\begin{array}{c}\text { Sum of } \\
\text { Squares }\end{array}$ & Df & Mean Square & $\mathbf{F}$ & Sig. \\
\hline \multirow[t]{3}{*}{1} & Regression & 2043.741 & 2 & 1021.870 & 39.923 & $.000^{\mathrm{a}}$ \\
\hline & Residual & 1766.134 & 69 & 25.596 & & \\
\hline & Total & 3809.875 & 71 & & & \\
\hline \multicolumn{5}{|c|}{ a. Predictors: (Constant), Pelatihan, Pendidikan } & & \\
\hline \multicolumn{7}{|c|}{ b. Dependent Variable: Kinerja } \\
\hline
\end{tabular}

Dari tabel diatas, dapat dilihat bahwa nilai $\mathrm{F}_{\text {Hitung }}$ sebesar 39,923, sedangkan $\mathrm{F}_{\text {tabel }}$ pada taraf signifikansi $(\alpha=0,05)$, dengan $\mathrm{dk}$ penyebut $=69$ dan $\mathrm{dk}$ pembilang $=47$ sebesar 2,974. Dengan demikian $\mathrm{F}_{\text {hitung }}>\mathrm{F}_{\text {tabel }}$.Hal ini menunjukkan bahwa $\mathrm{H}_{3}$ diterima, yang berarti bahwa hipotesis alternatif yang diajukan diterima semua variabel independen yaitu pendidikan dan pelatihan secara bersama-sama memiliki pengaruh yang signifikan terhadap kinerja pegawai.

\section{PEMBAHASAN}

Pengaruh Pendidikan terhadap Kinerja Pegawai

Hasil analisis data memperlihatkan bahwa pendidikan memiliki pengaruh possitif yang signifikan terhadap kinerja pegawai. Hasil penelitian ini juga sejalan dengan penelitian yang dilakukan oleh Haryanti dan Susialisasi (2008). Hasil penelitian tersebut menunjukkan bahwa tingkat pendidikan pegawai memilikipengaruh yang signifikan terhadap kinerja pegawai.Sementara itu, dalam penelitian yang dilakukan oleh Farida (2010) jugamenunjukkan bahwa tingkat pendidikan formal mempengaruhi kinerja pegawai.Hasil penelitian yang dilakukan oleh Sulistyaningsih juga menunjukkan hasil yang sama dengan penelitian ini, dimana tingkat pendidikan pegawai memiliki pengaruh yang signifikan terhadap kinerja pegawai.

Pendidikan merupakan faktor penting dalam menetukan kemarnpuan.kerjapegawai,karena pendidikan merupakan faktor yang bisa dijadikan alat untuk menilai dan melihat kemampuan seseorang dalarn menyelesaikan suatu pekerjaan. Menurut Hasibuan (2005) bahwa "pendidikan merupakan indikator yang mencerminkan kemampuan seseorang untuk dapat menyelesaikan suatu pekerjaan. Dengan latar belakang pendidikan pula seseorang dianggap mampu menduduki suatu jabatan". Pendidikan pada umumnya berkaitan dengan mempersiapkan calon tenaga yang diperlukan oleh suatu instansi atau organisasi, dimana dalam orientasi atau penekanannya, pendidikan lebih menekankan pada pengembangan kemampuan umum.

Pendidikan adalah suatu proses untuk meningkatnya keahlian teoritis, konseptual, dan moral pegawai. Pegawai yang mendapatkan pendidikan secara berencana dan yang memberikan kemungkinan untuk mengembangkan diri sendiri cenderung lebih dapat bekerja secara terampil jika dibandingkan dengan pegawai pada organisasi yang tidak memberikan kesempatan seperti itu. Dengan demikian program pendidikan berguna untuk menambah wawasan pegawai secara teoritis pada bidang pekerjaan sesuai dengan jabatannya, sehingga pendidikan mempunyai kualitas dan nilai bagi masyarakat

Pendidikan sekolah yang bersifat umum, pada dasamya hanya mengakibatkan penguasaan pengetahuan tertentu, yang tidak dikaitkan dengan jabatan atau tugas 
tertentu. Dengan menempuh tingkat pendidikan tertentu menyebabkan seorang pekerja memiliki pengetahuan tertentu. Orang dengankemampuan dasar apabila mendapatkan kesempatan-kesempatan pelatihan danmotivasi yang tepat, akan lebih mampu dan cakap untuk melaksanakan tugas-tugasnya dengan baik, dengan demikian jelas bahwa pendidikan akan mempengaruhi kinerja pegawai.

Peningkatan kinerja sebagai hasil dari peningkatan pendidikan pegawai, menjadikan instansi tempatnya bekerja akan berialan lebih efektif dan efisien sehingga instansi tersebut akan lebih mudah untuk mencapai tujuan. Oleh karena itu, peningkatan pendidikan mutlak diperlukan dalam hubungannya dengan peningkatan kinerja pegawai pada suatu instansi, termasuk di Dinas Pendidikan Pemuda dan Olahraga Kabupaten Dompu

Pengaruh Pelatihan terhadap Kinerja Pegawai

Hasil analisis data pengaruh pelatihan terhadap kinerja pegawai memperlihatkan bahwa pelatihan memiliki pengaruh yang signifikan terhadap kinerja pegawai. Penelitian ini menunjukkan hasil yang berbeda dengan hasil penelitian yang dilakukan oleh Supriadi (2013), yang memperlihatkan bahwa pelatihan tidak memiliki pengaruh yang signifikan terhadap kinerja pegawai. Akan tetapi penelitian ini sejalaan dengan beberapa penelitian terdahulu seperti Rama (2011) dan Dhafi (2011), keduanya menyimpulkan bahwa pendidikan dan pelatihan (diklat) yang diikuti pegawai berpengaruh terhadap kinerja pegawai. Sulistyaningsih (2008) juga menyimpulkan bahwa pelatihan berpengaruh terhadap kinerja pegawai.

Hasil penelitian ini selaras dengan pendapat Dessler (2004) bahwa pelatihan adalah proses mengajarkan keterampilan yang dibutuhkan karyawan baru untuk melakukan pekerjaannya. Rivai (2006) mengemukkan bahwa pelatihan merupakan bagian pendidikan yang menyangkut proses belajar untuk memperoleh dan meningkatkan keterampilan diluar sistem pendidikan yang berlaku dalam waktu yang relatif singkat dengan metode yang lebih mengutamakan pada praktik daripada teori. Pelatihan juga didefinisikan secara singkat sebagai suatu kegiatan untuk meningkatkan kinerja saat ini dan kinerja di masa mendatang.

Menurut Hardjanto (2012) berpendapat bahwa pelatihan adalah bagian dari pendidikan. Pelatihan bersifat spesifik, dan segera. Spesifik berarti pelatihan berhubungan dengan bidang pekerjaan yang dilakukan. Praktis dan segera berarti sudah dilatihkan dan praktikan.

Pengembangan pegawai sangat diperlukan dalam sebuah instansi, karena dengan adanya program tersebut dapat membantu meningkatkan kemampuan dan keterampilan pegawai. Pelatihan pegawai juga dirancang untuk memperoleh pegawai-pegawai yang mampu berprestasi dan fleksibel untuk suatu instansi dalam geraknya organisasi. Karena dengan meningkatnya kemampuan atau keterampilan para pegawai, dapat meningkatkan produktivitas kerja para pegawai. Produktivitas kerja meningkat berarti organisasi yang bersangkutan akan memperoleh keuntungan (Notoadmodjo, 2003:31)

Pelatihan juga merupakan upaya untuk mengembangkan kemampuan intelektual dan kepribadian pegawai. Dalam suatu pelatihan orientasi atau penekanannya pada tugas yang harus dilaksanakan (job orientation). Oleh karena itu setiap organisasi atau instansi yang ingin berkembang, pendidikan dan pelatihan pegawainya harus memperoleh perhatian yang lebih besar sehingga dapat meningkatkan kinerja pegawainya tersebut (Notoadmodjo, 2003:30)

1. Pengaruh Pendidikan dan pelatihan terhadap Kinerja Pegawai 
Hasil pengujian hipotesis simultan untuk membuktikan pengaruh pendidikan dan pelatihan terhadap kinerja pegawai memperlihatkan bahwa pendidikan dan pelatihan memiliki pengaruh positif dan signifikan terhadap kinerja pegawai. Besarnya pengaruh antara pendidikan dan pelatihan secara bersama-sama terhadap kinerja pegawai yaitu sebesar $53,6 \%$, dimana sisanya sebesar $46,4 \%$ dipengaruhi faktor lain yang tidak termasuk dalam penelitian.

Hasil penelitian ini sesuai dengan hasil penelitian yang dilakukan oleh Supriadi (2013), dan farida (2010). Penelitian dilakukan untuk melihat pengaruh pendidikan dan pelatihan terhadap kinerja pegawai. Hasil penelitian menunjukkan bahwa terdapat pengaruh yang positif dan signifikan secara simultan (bersama-sama) antara variabel pendidikan dan variabel pelatihan terhadap variabel terikat yaitu kinerja pegawai.

Hasil penelitian ini juga sesuai dengan penelitian yang dilakukan oleh Falery (2013) untuk melihat pengaruh pendidikan dan pelatihan, lingkungan kerja dan gaya kepemimpinan terhadap kinerja. Hasil penelitian ini selaras dengan pendapat Flippo (Hasibuan, 2001: 68) bahwa pendidikan dan pelatihan berhubungan dengan peningkatan pengetahuan umum dan pemahaman atas lingkungan kita secara menyeluruh. Sedarmayanti (2007: 379) bahwa pendidikan dan pelatihan adalah untuk meningkatkan keahlian dan atau keterampilan seseorang atau sekelompok orang dalam menangani tugas dan fungsi melalui prosedur sistematis dan terorganisasi yang berlangsung dalam waktu yang relatif singkat.

Pendidikan dan pelatihan adalah merupakan upaya untuk pengembangan sumber daya manusia, terutama untuk pengembangan aspek kemampuan intelektual dan kepribadian manusia. Pendidikan dan pelatihan tidak saja menambah pengetahuan, akan tetapi juga meningkatkan keterampilan bekerja, dengan demikian meningkatkan produktivitas kerja. Pendidikan pada umumnya berkaitan dengan mempersiapkan calon tenaga yang didiperlukan oleh suatu instansi atau organisasi, sedangkan pelatihan lebih berkaitan dengan peningkatan atau keterampilan pegawai yang sudah menduduki suatu pekerjaan atau tugas tertentu.

Dalam suatu pelatihan orientasi atau penekanannya pada tugas yang harus dilaksanakan (job orientation), sedangkan pendidikan lebih pada pengembangan kemampuan umum. Dalam rangka meningkatkan pengetahuan, ketrampilan serta sikap-sikap kerja yang kondusif bagi penampilan kinerja pegawai, diselenggarakan pendidikan dan pelatihan pegawai, dan diklat pegawai ini didasarkan atas analisis kebutuhan yang memadukan kondisi nyata kualitas tertentu selaras dengan program rencana jangka panjang organisasi.

Dengan adanya pendidikan dan pelatihan, kualitas kerja pegawai akan menjadi lebih baik berdasarkan kemampuan dan keahlian yang dimilikinya. Pegawai akan mengerahkan segenap kemampuan yang dimiliki dalam melaksanakan tugasnya sebagai pegawai Dinas Pendidikan Pemuda dan Olahraga Kabupaten Dompu. Selain itu, tingkat pendidikan yang tinggi akan membuat pegawai lebih kompeten dalam bekerja, sebaliknya tingkat pendidikan yang rendah akan membuat pegawai tidak melaksanakan tugas yang diberikan dengan maksimal. Kedua variabel ini, dengan variabel-variabel yang lain yang tidak diteliti dalam penelitian ini, mempengaruhi baik buruknya kinerja seorang pegawai. 


\section{KESIMPULAN}

Berdasarkan hasil analisis data dan pembahasan hasil penelitian dapat disimpulan hal-hal sebagai berikut :

1. Pendidikan secara parsial berpengaruh positif dan signifikan terhadap kinerja pegawai di Lingkungan Dinas Pendidikan Pemuda dan Olahraga Kabupaten Dompu. Artinya semakin tinggi pendidikan pegawai maka semakin tinggi kualitas kemampuan professional individu pegawai.

2. Pelatihan secara parsial berpengaruh positif dan signifikan terhadap kinerja pegawai di Lingkungan Dinas Pendidikan Pemuda dan Olahraga Kabupaten Dompu. Artinya semakian sering pegawai mengikuti pelatihan maka semakin terampil dan mahir dalam melaksanakan pekerjaan diberikan.

3. Pendidikan dan Pelatihan secara simultan berpengaruh positif dan siginifikan terhadap kinerj pegawai pada pegawai di Lingkungan Dinas Pendidikan Pemuda dan Olahraga Kabupaten Dompu. Artinya semakin tinggi pendidikan dan semakin sering pegawai mengikuti pelatihan maka semakin tinggi kualitas, keterampilan dan kemampuan dalam melaksanakan pekerjaan yang berikan.

\section{DAFTAR PUSTAKA}

Arikunto, S. (2006). Prosedur Penelitian. Suatu Pendekatan Praktek. Jakarta: PT.Rineka Cipta.

Andersen. (2013). Pengaruh Pendidikan Pelatihan dan Motivasi Kerja Terhadap Kinerja Pegawai Pada Badan Kepegawaian Daerah Kabupaten Dompu. Tugas Akhir Program Magister. Jakarta: Universitas Terbuka.

Arifuddin. (2013). Pengaruh Pendidikan Pelatihan dan Lingkungan Kerja Terhadap Kinerja Kepala Desa di Kabupaten Indragiri Hilir. Tugas Akhir Program Magister. Jakarta: Universitas Terbuka.

Bungin, B. (2005). Metodologi Penelitian Kuantitatif Komunikasi, Ekonomi, dan Kebijakan Publik serta Ilmu-Ilmu Sosial Lainnya, Edisi Pertama, Cetakan Pertama, Jakarta: Prenada Media.

Dhafi. (2011). Analisis Pengaruh Pendidikan Dan Pelatihan Serta Pengembangan Karir Terhadap KinerjaPersonil Satlantas Pada Unit Penegakan Hukum dan Penyidikan Kecelakaan Kepolisian Resort di Deli Serdang. Tesis. Medan: Sekolah Pascasarjana Universitas Sumatera Utara.

Farida, I. (2010). Pengaruh Pendidikan Formal, Pelatihan, dan Pengembangan Karier terhadap Kinerja Pegawai Perempuan (Studi dI Kola Bandar Lampung). Tesis. Bandung: Sekolah Pascasarjana Universitas Padjadjaran.

Falery T. (2013). Pengarug Pendidikan dan Pelatihan Lingkungan Kerja dan Gaya Kepemimpinan Terhadap Kinerja Anggota Satuan Polisi Pamong Praja Provinsi Kalimantan Tengah. Tugas Akhir Program Magister. Jakarta: Universitas Terbuka.

Ghozali, I. (2005). Aplikasi Analisis Multivariate dengan Program SPSS.Semarang: Badan Penerbit Universitas Diponegoro

Hardjanto, Imam. (2012). Manajemen Sumber Daya Aparatur. Malang

Harianto, S. (2007). Pengaruh Pendidikan dan Pelatihan Terhadap Kinerja Karyawan pada Kantor Pelayanan Bea dan Cukai Palembang. Tesis. Palembang: Sekolah Pascasarjana Universitas Sriwijaya. 
Haryanti dan Susialisasi. (2008). Pengaruh Tingkat Pendidikan, Lingkungan Kerja dan Masa Kerja Terhadap Kinerja Kepala Sekolah SMP Negeri Se-Kabupaten Karanganyar Dengan Gender Sebagai Variabel Moderator. Tesis. Surakarta: Sekolah Pascasarjana STIE AUB.

Hasibuan, M, SP. (2002). Organisasi dan Motivasi. Bandung: Bumi Aksara. 2005. Manajemen Sumber Daya Manusia. Edisi Revisi, Cetakan Kedelapan, Jakarta: Bumi Aksara.

Notoatmodjo, S. (2003).Pengembangan Sumba Daya Manusia. Cetakan Ketiga. Jakarta: PT. Rineka Cipta.

Peraturan Pemerintah Nomor 101 Tahun 2000 tentang Pendidikan dan Pelatihan Jabatan Pegawai Negeri Sipil.

Priyatno, D. (2008). Mandiri Belajar SPSS Untuk Analisa Data Dan Uji Statistik. Yogyakarta: Mediacom.

Putra, INNA, (2006). Analisis Biaya Keagenan Terhadap Kebijakan Dividen Pada Perusahaan Manufaktur yang terdaftar di Bursa Efek Jakarta, Jurnal Riset Akuntansi, Vol.5, No.2, 37-47.

Putra, INNA, (2007). Analisis Sensitifitas Saham Pada Perusahaan Property dan Real Estate yang Terdaftar di Bursa Efek Jakarta, ORYZA, Vol.6, No.2, 252-268.

Riduan (2008).Metode dan Teknik MenyusunThesis. Bandung: Alfabeta.

Rivai, V. (2006).Manajemen SDM untuk Perusahaan: Dari Teori ke Praktik. Jakarta: PT Raja Grafindo Persada.

Sedarmayanti. (2004). Pengembangan Kepribadian Pegawai, Cetakan Pertama, Bandung: Bandar Maju.

Sedarmayanti. (2007). Manajemen Sumber Daya Manusia Reeformasi Birokrasi dan Manajemen Pegawai Negeri Sipil, Bandung: Refika Aditama.

Siregar, Syofian. (2014). Statistik Parametrik Untuk Penelitian Kuantitatif. Jakarta: Bumi Aksara.

Sulistyaningsih. (2008). Pengaruh Pendidikan dan Pelatihan (Diklat), Lingkungan Kerja, Tingkat Pendidikan dan Kepemimpinan Terhadap Kinjer Pegawai Negeri Sipil pada Dinas Pendidikan dan Kebudayaan Kabupaten Karanganyar. Tesis. Surakarta: Sekolah Pascasarjana STIE AUB

Supriadi. (2013). Pengaruh Pendidikan dan Pelatihan Terhadap Kinerja Pegawai di Lingkungan Unit Pelaksana Teknis Dinas Pendidikan, Kebudayaan, Pemuda dan Olahraga Kecamatan VII Koto Ilir Kabupaten Tebo. Tugas Akhir Program Magister. Jakarta: Universitas Terbuka.

Sugiyono. (2007). Metode Penelitian Bisnis. Edisi Kesepuluh. Bandung: Alfabeta

Supangat. (2010). Pengaruh Pendidikan dan Pelatihan Serta Lingkungan Kerja Terhadap Kinerja Pegawai Pembimbing Kemasyarakaion Balai Pemasyarakatan Klas I Medan. Tesis. Medan: Sekolah Pascasarjana Universitas Sumatera Utara

Umar, H. (2005.) Metode Penelitian Untuk Skripsi dan Tesis Bisnis. Jakarta: PT. Raja Grafindo Persada.

18 | Pengaruh Pendidikan Dan Pelatihan Terhadap Kinerja Pegawai... 